\title{
Improving the Breaking and Tear Strength of Cotton Fabric Using BTCA and CA Crosslinkers
}

\author{
Aslıhan KORUYUCU ${ }^{* 1}$ ORCID 0000-0002-8443-5188 \\ ${ }^{1}$ Namık Kemal University, Çorlu Faculty of Engineering, Department of Textile \\ Engineering, Tekirda $\breve{g}$
}

Geliş tarihi: 24.05 .2021

Kabul tarihi: 10.12 .2021

Atıf şekli/ How to cite: KORUYUCU, A., (2021). BTCA ve CA Çapraz Bağlayıcılar Kullanılarak Pamuklu Kumaşın Kopma ve Yırtılma Mukavemetinin Geliştirilmesi. Çukurova Üniversitesi, Mühendislik Fakültesi Dergisi, 36(4), 1061-1072.

\begin{abstract}
Polycarboxylic acids are used as crosslinking agents with sodium hypophosphite which do not contain formaldehyde. In this study, breaking strength, breaking elongation and tear strength of cotton(twill weave)fabric samples were determined by using twill fabrics, six different coating recipes, produced with $100 \%$ cotton yarns. The results of breaking strength, breaking elongation and tear strength testing were compared according to the fabric structure, coating recipes and crosslinker structure statistically. A significant increase in tensile strength was observed after coating with $1 \mathrm{~g} \mathrm{Cu}_{2} \mathrm{O} \mid<5 \mu \mathrm{m}, \mathrm{CuO}<5 \mu \mathrm{m}$,

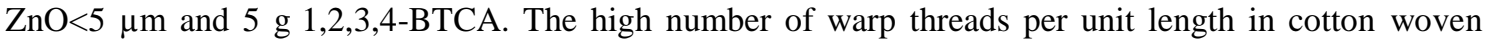
fabric leads to an increase in tensile strength. The best results in tensile strength and elongation at break experiments were obtained after the reaction of polyacrylate binder with BTCA and ZnO microparticles.
\end{abstract}

Keywords: Woven fabric, Breaking and Tearing strength, Breaking elongation, Coating recipes, Crosslinker structure

\section{BTCA ve CA Çapraz Bağlayıcılar Kullanılarak Pamuklu Kumaşın Kopma ve Yırtılma Mukavemetinin Geliştirilmesi}

$\ddot{\mathbf{O} z}$

Polikarboksilik asitler, sodyum hipofosfit ile formaldehit içermeyen çapraz bağlayıcı maddeleri olarak kullanılmaktadır. Bu çalışmada, \%100 pamuk dimi yapısında kumaşlar kullanılarak altı farklı kaplama reçetesi ile kumaşın kopma, uzama ve yırtılma mukavemetleri belirlenmiştir. Kullanılan kumaş cinsine, kaplama reçetesine ve çapraz bağlayıcı yapısına göre elde edilen sonuçlar karşılaştırılmış ve istatiksel

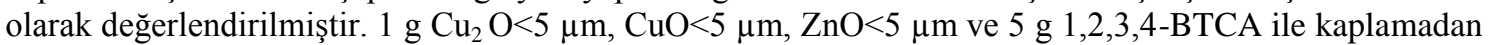
sonra kopma mukavemetinde önemli bir artış gözlenmiştir. Pamuklu dokuma kumaşta birim uzunluktaki

*Sorumlu yazar.(Corresponding author): Aslıhan KORUYUCU, adelituna@nku.edu.tr 
çözgü iplik sayısının fazla olması, çekme mukavemetinin artışına yol açmaktadır. Kopma mukavemeti ve kopma uzamasında en iyi sonuç; poliakrilat binderin BTCA ve $\mathrm{ZnO}$ mikro partikülü ile reaksiyonu sonrasında elde edilmiştir.

Anahtar Kelimeler: Dokuma kumaş, Kopma ve Yırtılma mukavemeti, Kopma uzaması, Kaplama reçetesi, Çapraz bağlayııı yapısı

\section{INTRODUCTION}

Surface coating of textile materials with chemical constructions have been developed permanently for several most recent decades. The essential substrate of the surface material is mainly textile fabric and it is coated on one or both surfaces with one or more polymer layers. These kind of products with the essential textile material have numerous improved properties and various advantages over the classic textile material [1-3].

Cotton has inadequate increased resistance owing to its free hydroxyl groups. To improve the crease cure property of cotton, the free hydroxyl groups are cross-linked by applying general aldehyde and non-general aldehyde based crosslinking agents.

The applied polymer layer can be polyacrylate. Acrylate polymers are the group of polymers which could be mentioned to plastics and frequently known as acrylics or polyacrylates. They are defined by their transparancy and elasticity $[1,2]$. Acrylic polymers display different properties depending on their chain length, their degree of crosslinking and the nature of crosslinking agent used. Linear acrylic polymers with short chain length are water soluble and they are used for their metal quenching properties.

Acrylates are the esters, salts and conjugate bases of acrylic acid with its derivatives. They are made from acrylate monomer, which commonly consists of esters which includes vinyl groups, that is two carbon atoms that are double-bonded to each other, and straight attached to the carbonyl carbon of the ester group.

Butyl acrylate derivatives could be used to improve the impact strength of breaking, elongation and tearing [4-7].
Acrylates are used for many applications, such as mainly in cosmetics, adhesives, textile, paints, and biomedical applications. However, acrylate polymers suffer some disadvantages such as low mechanical properties at ambient or high temperatures, particularly above their glass transition temperature. They are used not only coating, but also printing purposes $[3,8]$.

When the polycarboxylic acid crosslinks with cellulose, after that an anhydride ring is esterified with a hydroxyl group of cellulose, and the nonesterified carboxyl group remains.

BTCA satisfies many desirable requirements such as durable press performance. However, it results more loss in tensile strength and abrasion resistance [9].

Tensile strength loss is attributed to acid catalyzed depolymerization and cellulosic crosslinking [9], whereas abrasion resistance loss is associated with irreversible acid catalyzed depolymerization and reversible crosslinking of cellulose molecules[10]. Polymer additives have been used mainly in conventional cotton crosslinking to improve wrinkle properties [11,12], abrasion resistance [13], tear strength [14], as well as to inhibit uneven crosslink distribution during drying of cotton textiles i.e. to inhibit migration [15].

The loss of tensile strength of 1,2,3,4butantetracarboxylic acid (BTCA) treated cotton was found to be caused by acid degradation and crosslinking. [16]. Pre-cationization of the cotton fabric with an ammonium citrate and sodium hypophosphite, followed by ionic crosslinking, results in a slightly better tensile strength [25].

Since twill fabrics have a slight loose structure, the yarns slip over each other at the time of tearing, stretch and tear later [26]. 


\section{REVIEW OF LITERATURE}

There are some research works, where different types of crosslinking agents are used in cotton fabric strength. Yang et al. [17] have studied the relationship between fabric tensile strentgh loss and the molecular structures of crosslinking agents. Yang et al. also compared that the tensile strength loss of cotton treated with DMDHEU and DHDMI.

Refaie. [18] has studied that the addition of CMC alone or in combination with chitosan $(0.5 \%)$ to BTCA finishing improved crease recovery angle, tensile strength, abrasion resistance. Chen [19] investigated that the cause and mechanism of loss in abrasion resistance of cross-linked cotton fabrics. And also developed that the relationship between the molecular structure of cross-linking agents and the mechanical properties of crosslinked textile structures. Weilin $\mathrm{Xu}$ et al [20-22] performed a treatment on cotton fabrics at different curing temperatures with different concentrations of 1,2,3,4-butanetetracarboxylic acid (BTCA) catalyzed with sodium hypophosphite (SHP). Strength retention and wrinkle recovery angle (WRA) were tested and the results declared that high curing temperature and high BTCA concentration reduced fabric strength. Weilin $\mathrm{Xu}$ [23] made a treatment on cotton fibers and their fabric with BTCA with the catalyst SHP at different concentrations of treating agent and different curing temperatures. Results showed that low curing temperatures and low agent concentrations have a slight effect on the reduction of crystallinity and crystallite size. Initial slight crystallinity loss induced high strength loss in the fabric. Spencer [24] made a treatment on $100 \%$ plain weave cotton fabric which has been scoured, desized, bleached, and heat set.

The optimal treatment involved carboxy methylation in two steps. The optimal treatment was to provide the largest increase in dry WRA, the largest increase in wet WRA, the best DP rating and moderate increases in strength and elongation.

In this study, the $\mathrm{Cu}_{2} \mathrm{O}, \mathrm{CuO}$ and $\mathrm{ZnO}$ microparticles and 1,2,3,4-butantetracarboxylic acid (BTCA), citric acid monohydrate (CA) and sodium hypophosphite (SHP) were used as crosslinking agents to improve the mechanical properties of cotton fabrics.

\section{MATERIALS AND METHODS}

\subsection{Materials}

$100 \%$ cotton fabric was used for this study which was selected due to its wide usage in denim shirt fabric.

The substrates were characterised with respect to their weight and thickness, the data of which is shown in Table 1.

The cotton fabric had a twill weave, with a unit weight of $336.79 \mathrm{~g} / \mathrm{m}^{2}$, and a thickness of 0.4545 mm. Copper (I) oxide, copper (II) oxide and zinc oxide particles below $5 \mu \mathrm{m}$ (Sigma Aldrich) pattern were used as supplied.

\section{Cross-linkings}

At high temperatures, carboxylic acids generate ester-type crosslinking with cellulose molecules and provide mechanical performance. For this purpose, BTCA and CA were used in this study. Since these two carboxylic acids make effective cross-linking in the combined use of phosphorousincluding acids with inorganic salts, SHP was added as a catalyst in pre-treatment bath. The composition of pre-treatment baths including BTCA and SHP, and CA and SHP were indicated in Table 1.

Properties of commercial samples were given in Table 2. As the thickener, anionic polyacrylate polymer dispersion was used. Density of the thickener was $1.1 \mathrm{~g} / \mathrm{cm}^{3}$ at $20^{\circ} \mathrm{C}$ and the $\mathrm{pH}$ was 6 . 
Table 1. Composition of pre-treatment baths

\begin{tabular}{|l|c|c|c|c|}
\hline Treatments & $\begin{array}{c}\text { BTCA, } \\
\text { gram }\end{array}$ & $\begin{array}{c}\text { CA, } \\
\text { gram }\end{array}$ & $\begin{array}{c}\text { SHP, } \\
\text { gram }\end{array}$ & $\begin{array}{c}\text { Pure } \\
\text { water, } \\
\mathrm{ml}\end{array}$ \\
\hline $\begin{array}{l}2,5 \% \text { BTCA } \\
+1 \% \text { SHP }\end{array}$ & 30 & - & 12 & 1000 \\
\hline $\begin{array}{l}2,5 \% \mathrm{CA} \\
+1 \% \text { SHP }\end{array}$ & - & 30 & 12 & 1000 \\
\hline
\end{tabular}

The commercially conventional polyacrylate polymers were supplied from CHT. Tubicoat A41 and A17 are water based acrylate binders, Rucocoat TH 5020 are a acrylate synthetic thickener from Rudolf-Duraner. The coating was applied by laboratory type blade coating machine (Ataç Machine Corp, RKL40). The coating density was applied by working at one blade distance $(0.1$ $\mathrm{mm})$.

The coated fabrics were dried at $100{ }^{\circ} \mathrm{C}$ for $2 \mathrm{~min}$ and then cured at $160{ }^{\circ} \mathrm{C}$ for $2 \mathrm{~min}$.

In this study, cotton woven fabrics coating with BTCA-sodium hypofosfite.

Table 2. Commercial samples

Table 2. Commercial samples
\begin{tabular}{|l|l|}
\hline $\begin{array}{l}\text { Fabric } \\
\text { Code }\end{array}$ & $\begin{array}{l}\text { Particle/crosslinking structure/coating } \\
\text { thickness }(\mathrm{mm})\end{array}$ \\
\hline PA 1a & $\begin{array}{l}\mathrm{Cu}(\mathrm{I}) \mathrm{O}<5 \mu \mathrm{m}+1,2,3,4- \\
\text { butantetracarboxylic acid/0.1 mm }\end{array}$ \\
\hline PA 2a & $\begin{array}{l}\mathrm{Cu}(\mathrm{II}) \mathrm{O}<5 \mu \mathrm{m}+1,2,3,4- \\
\text { butantetracarboxylic acid/0.1 mm }\end{array}$ \\
\hline PA 3a & $\begin{array}{l}\text { ZnO }<5 \mu \mathrm{m}+1,2,3,4- \\
\text { butantetracarboxylic acid} / 0.1 \mathrm{~mm}\end{array}$ \\
\hline PA 1b & $\begin{array}{l}\mathrm{Cu}(\mathrm{I}) \mathrm{O}<5 \mu \mathrm{m}+\text { citric acid } \\
\text { monohydrate/0.1 mm }\end{array}$ \\
\hline PA 2b & $\begin{array}{l}\mathrm{Cu}(\mathrm{II}) \mathrm{O}<5 \mu \mathrm{m}+\text { citric acid } \\
\mathrm{monohydrate} / 0.1 \mathrm{~mm}\end{array}$ \\
\hline PA 3b & $\begin{array}{l}\mathrm{ZnO}<5 \mu \mathrm{m}+\text { citric acid monohydrate/ } \\
0.1 \mathrm{~mm}\end{array}$ \\
\hline
\end{tabular}

PA 1a sample which was treated with $\mathrm{Cu}(\mathrm{I}) \mathrm{O}<5 \mu \mathrm{m}$ via 1,2,3,4-butan tetracarboxylic acid crosslinking with $0.1 \mathrm{~mm}$ coating thickness polyacrylate binder.

PA 2a sample which was treated with $\mathrm{Cu}(\mathrm{II}) \mathrm{O}<5$ $\mu \mathrm{m}$ via 1,2,3,4-butan tetracarboxylic acid crosslinking with $0.1 \mathrm{~mm}$ coating thickness polyacrylate binder.

PA 3a sample which was treated with $\mathrm{ZnO}<5 \mu \mathrm{m}$ via 1,2,3,4-butan tetracarboxylic acid crosslinking with $0.1 \mathrm{~mm}$ coating thickness polyacrylate binder.

PA1b sample which was treated with $\mathrm{Cu}(\mathrm{I}) \mathrm{O}<5 \mu \mathrm{m}$ via citric acid monohydrate crosslinking with $0.1 \mathrm{~mm}$ coating thickness polyacrylate binder.

PA2b sample which was treated with $\mathrm{Cu}(\mathrm{II}) \mathrm{O}<5$ $\mu \mathrm{m}$ via citric acid monohydrate crosslinking with $0.1 \mathrm{~mm}$ coating thickness polyacrylate binder.

PA3b sample which was treated with $\mathrm{ZnO}<5 \mu \mathrm{m}$ via citric acid monohydrate crosslinking with $0.1 \mathrm{~mm}$ coating thickness polyacrylate binder.

\subsection{Mechanical Performance Tests}

ISO test methods 13937-1, 13934-2 and 12947-3; 12947-4 were used for tear strength, breaking strength and Martindale abrasion fabric testing. All fabrics were taken into consideration in the warp and weft directions.

The tear resistance of fabrics are attributed by different methods of sample preparation, their shape and size [5].

Tear strength properties (warp and weft direction) were measured by using ballistic pendulum method (Elmendorf) according to PN-EN ISO 13937-1:2000 standard. In Figure 1, the Elmatear model 455 for the dynamic tear test was presented.

The method of sample preparation and the initial length between jaws was kept at $20 \pm 0.5 \mathrm{~mm}$ and the tear distance is $43 \pm 0.5 \mathrm{~mm}$ as shown in Figure 2 . 


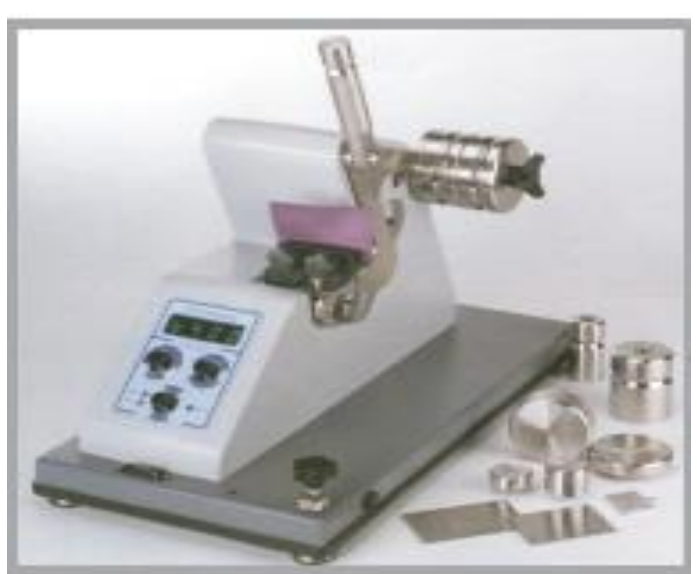

Figure 1. Elmatear device

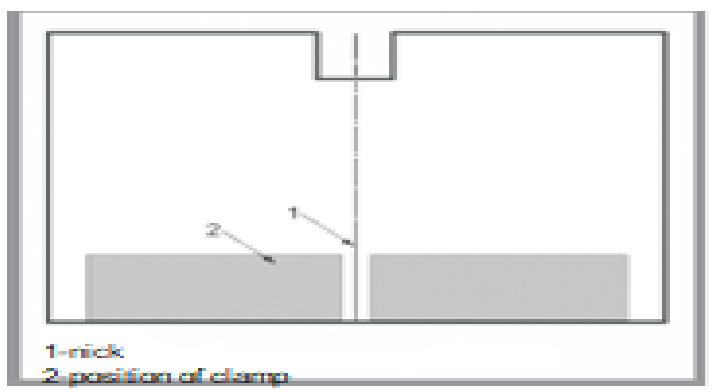

Figure 2. Method of sample preparation and the initial length in the Elmatear according to PN-EN ISO 13937-1:2002

\subsubsection{Breaking Test Results}

Cotton fabrics coated with a polyacrylate binder were subjected to physical tests to maintain their resistance to mechanical stress. The general purpose of the analysis was to indicate distribution of maximum principal stress, loss in weight and obtain the tensile strength.

The loss of tensile strength obtained with polycarboxylic acid crosslinking was attributed to the inflexibility of the crosslinking itself, as well as the uneven heating in the curing step [27].

Carboxylic groups on BTCA react with the hydroxyl groups on cellulose to form ester bonds (Figure 3).

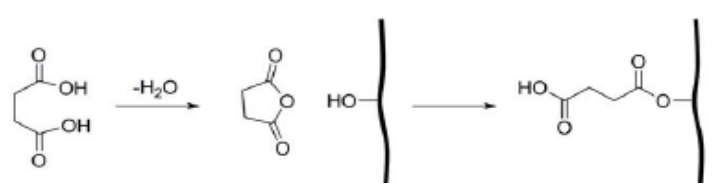

Figure 3. Formation of ester linkages between poly carboxylic acid and hydroxyl groups on cellulose

In this respect, the acids that have been studied usually have the smallest three carboxylic or two groups which were required to form each cyclic anhydride. Examples include 1,2,3,4butantetracarboxylic acid (BTCA) [25-33].

Polycarboxylic acids have to form an anhydride intermediates esterify cotton cellulose [30].

1,2,3,4-butantetracarboxylic acid (BTCA) and citric acid monohydrate (CA) work as cotton crosslinkers by covalently bonding to cellulose fibers [29].

Finally, pre-cationization of the fabric with an ammonium reagent, followed by ionic crosslinking, has also been shown to improved tensile strength [34].

In order to determine the effects of coating parameters, the breaking and tear strength test results were evaluated. Breaking strength and extension values of raw cotton fabrics coated with soft polyacrylate binders are given in Table $3[6,7]$.

Table 3. Comparison of breaking strength and extension test results

\begin{tabular}{|l|c|c|c|c|}
\hline & \multicolumn{2}{|c|}{$\begin{array}{c}\text { Breaking Strength } \\
(\mathrm{N})\end{array}$} & \multicolumn{2}{c|}{$\begin{array}{c}\text { Extension } \\
(\mathrm{mm})\end{array}$} \\
\hline & Weft & Warp & Weft & Warp \\
\hline Uncoated & 205.8 & 491.3 & 12 & 14.86 \\
\hline $\begin{array}{l}\text { BTCA+ } \\
\mathrm{ZnO}\end{array}$ & 796.4 & 826.9 & 14.96 & 25.61 \\
\hline $\begin{array}{l}\mathrm{CA}+ \\
\mathrm{ZnO}\end{array}$ & 445.9 & 786.1 & 16.55 & 26.69 \\
\hline $\begin{array}{l}\mathrm{BTCA} \\
\mathrm{Cu}(\mathrm{I}) \mathrm{O}\end{array}$ & 510.8 & 794.6 & 14.25 & 27.24 \\
\hline $\begin{array}{l}\mathrm{CA}+ \\
\mathrm{Cu}(\mathrm{I}) \mathrm{O}\end{array}$ & 256.3 & 735.2 & 44.33 & 15.36 \\
\hline $\begin{array}{l}\mathrm{BTCA}+ \\
\mathrm{Cu}(\mathrm{II}) \mathrm{O}\end{array}$ & 605.2 & 780.8 & 13.88 & 26.37 \\
\hline $\begin{array}{l}\mathrm{CA}+ \\
\mathrm{Cu}(\mathrm{II}) \mathrm{O}\end{array}$ & 444.5 & 776.7 & 14.40 & 26.63 \\
\hline
\end{tabular}


A major increase in breaking force in both warp and weft directions were obtained when compared to those of uncoated fabrics. Example breaking test plots from warp direction testing (which means weft yarns were broken) were shown in Figure 4.

As a consequence, the uncoated samples in the breaking load test caused less bending than to the coated samples.

Coating application increased the breaking load considerably. As shown in Figure 4, the polyacrylate binder coating a significantly increased the breaking strength, particularly in the warp direction. The coating penetrated the fabric structure well to hold the yarns together and this had a tendency to cause the particular thread breaking. The more carboxylic groups in the crosslinker increase, the more increase in breaking strength is obtained.

When the strength comparison in the warp and the weft direction are examined, it is was determined that noticeable changes in breaking strength (Figure 4) were obtained. This is an expected result. The higher number of yarns (thickness) per unit length in the warp direction in woven fabrics increases the breaking strength [35].

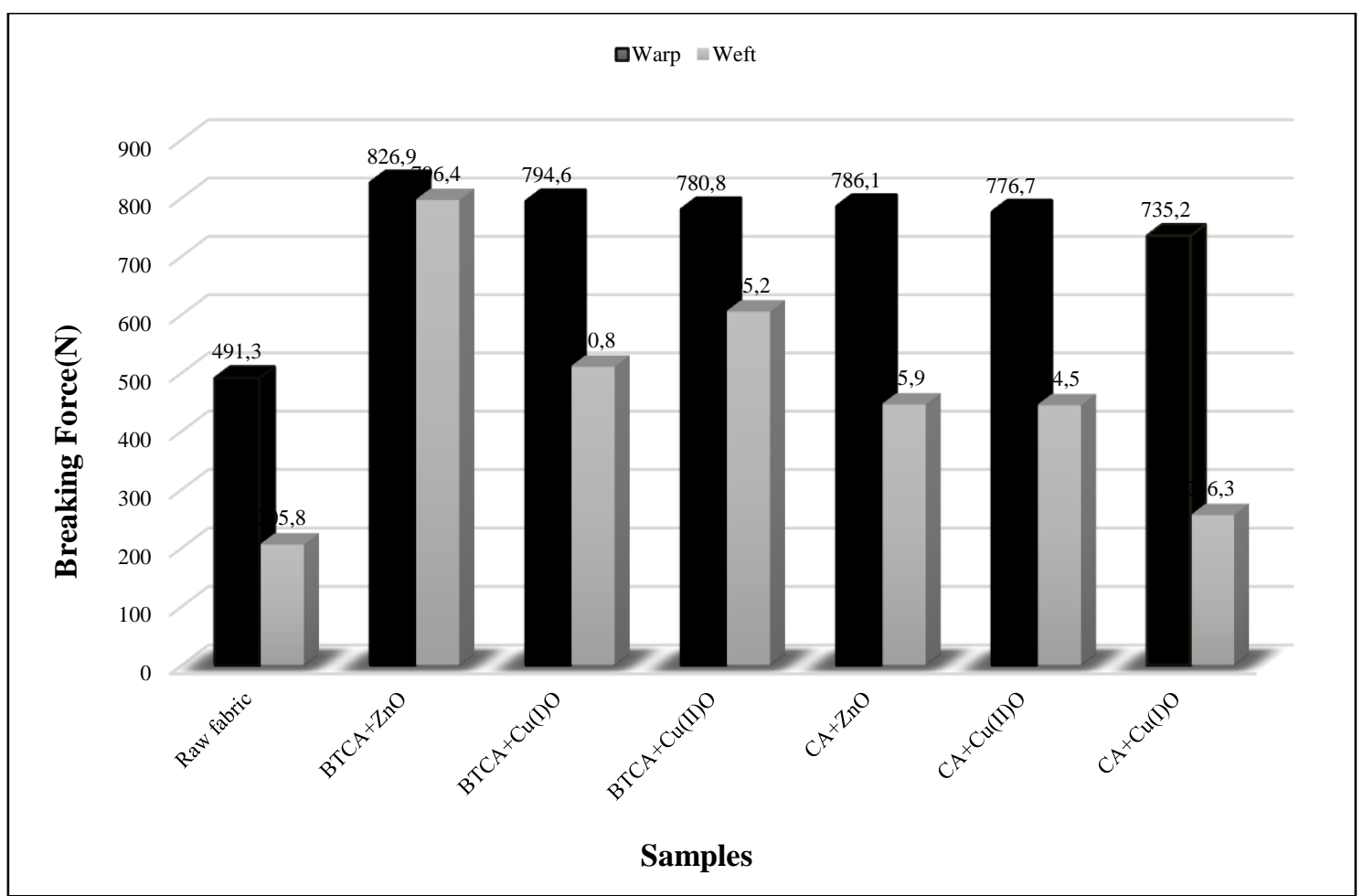

Figure 4. Breaking load test results

In addition to the elongation of the woven fabric itself, the relationship between coating thickness and crosslinkings plays an important role.

After the coating process with $1 \mathrm{~g} \mathrm{Cu}_{2} \mathrm{O}<5 \mu \mathrm{m}$,

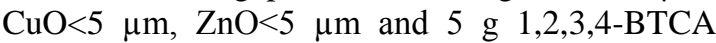
chemical structure, a higher increase in the breaking strength was noticed.
BTCA has four carboxylic acid groups and a vinyl double bond. Since it generates two or more ester bonds, two macromolecules can be crosslinked more effectively. CA has three carboxylic acid groups and no vinyl double bonds. Carboxyl groups in CA are less reactive in cellulose esterification. Therefore, the crosslinking effects are not good as BTCA. The number of crosslinks 
generated after the application increases breaking strength.
Example elongation at breaking strength plots from weft and warp direction testing (meaning fill yarns broke) are shown in Figure 5.

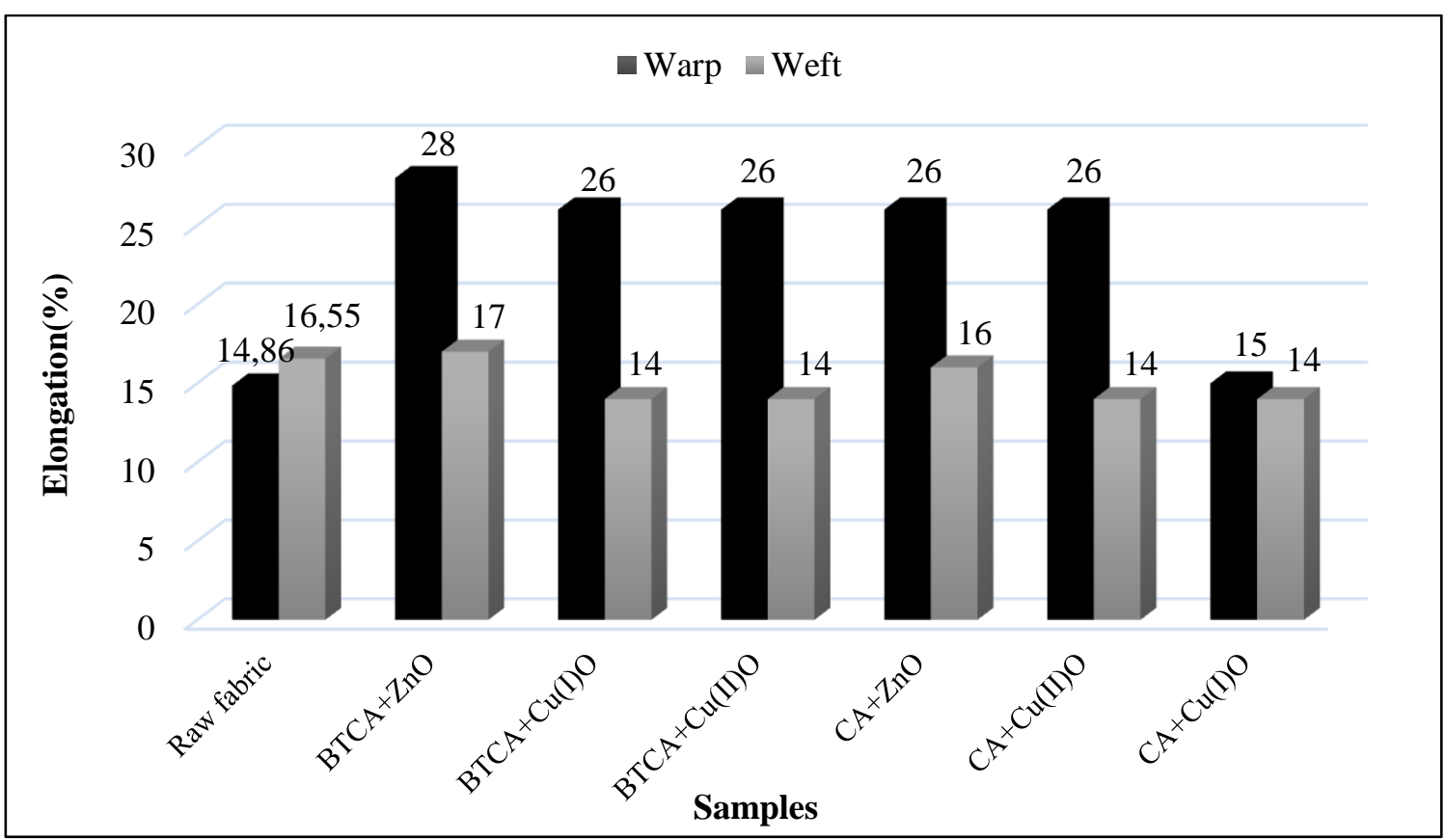

Figure 5. Elongation test results fabrics

As shown in Figure 5, the elongation at break increases more than the reference.

Moreover in weft direction, the same or slightly lower elongation at break values were obtained after coating with two crosslinkers according to the reference.

When the results of the elongation at break test are examined, it was observed that the results of coated fabrics and raw fabrics were close to each other in the weft direction. The highest breaking elongation in weft and warp direction was obtained by using BTCA+ $\mathrm{ZnO}$ acrylic coating.

Because of the application of the coating in the warp direction, the acrylic coating with the crosslinker affect the $28 \%$ elongation more in the warp.

\subsubsection{Tearing Test Results}

Tear resistance is one of the important properties of the fabric. Tear strength of a fabric refer to its resistance to tearing force.

The tear test results evaluated in Figure 6. They show decrease in tear strength in both warp and weft directions approximated to those of uncoated.

Warp tear strength decreases after the coating process. Weft tear strength increases after $\mathrm{BTCA}+\mathrm{Cu}(\mathrm{I}) \mathrm{O}, \mathrm{BTCA}+\mathrm{Cu}(\mathrm{II}) \mathrm{O}$ and $\mathrm{CA}+\mathrm{Cu}(\mathrm{II}) \mathrm{O}$ coating processes.

As seen in Figure 7, the more shrinkage in length is observed in the coated samples. 


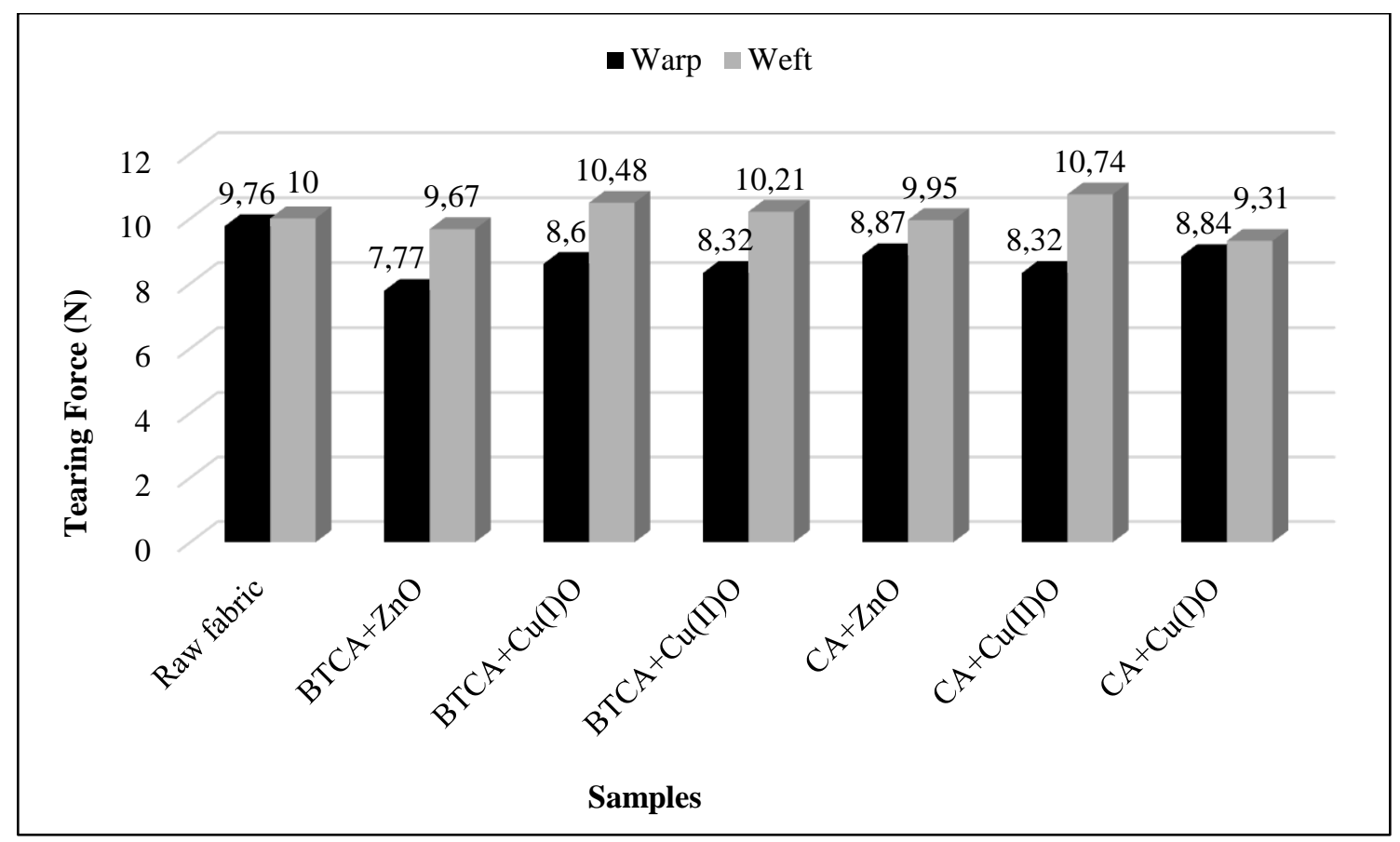

Figure 6. Tearing test results

As shown in Figure 6, the decrease tearing strength is observed when compared to the reference.

In the weft direction; there was no significant change in tearing strength relative to the reference.

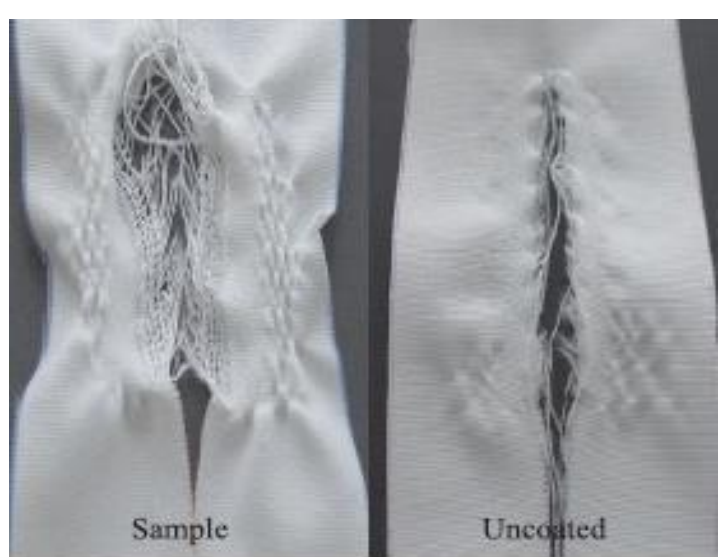

Figure 7. Samples of polyacrylate coated and uncoated fabrics in the warp direction

The tensile strength of a fabric, which is its resistance when a load is applied in the warp and weft direction, is affected to some extent by the construction or every property of the coating with crosslinker.

Tear strength in woven fabrics; it depends on many factors such as fiber, yarn and fabric properties and coating processes applied to the fabric. Therefore, different results can be obtained after coating.

The curing at $160{ }^{\circ} \mathrm{C} 2 \mathrm{~min}$ reduced the tensile strength of fabric owing to more esterification and crosslinking, when it was treated with BTCA/SHP.

The same tendency has been followed for tear strength.

\subsection{Statistical Analysis}

The resulting model is statistically significant at $\alpha=0.01$ with $\mathrm{R}=0.95$ and $\mathrm{R}^{2}=0.9025$. The significant factors are coating recipes.

In this study, the effect of the coating recipes used on the breaking, elongation and tearing strentgh 
values in the warp and weft directions were determined by performing a one-way analysis of variance in the SPSS statistical program representations were given in Table 8-12 and Figure 8. As seen in Table 13, the lowest tensile, elongation and tear strength values were obtained at $\mathrm{PA} 1 \mathrm{~b}(\mathrm{Cu}(\mathrm{I}) \mathrm{O}<5 \mu \mathrm{m}+\mathrm{CA})$. The highest strength values were obtained in $\mathrm{PA} 3 \mathrm{a}(\mathrm{ZnO}<5 \mu \mathrm{m}+\mathrm{BTCA})$. Evidently, BTCA is more effective for esterifying cotton cellulose than is CA. Previous research also indicated that cotton fabric treated with BTCA forms a higher amount of ester than that treated with CA [21].

Table 8. Ranks

\begin{tabular}{|c|c|c|c|}
\hline & $\begin{array}{c}\text { Warp } \\
\text { Weft }\end{array}$ & $\begin{array}{c}\text { N Mean } \\
\text { Rank }\end{array}$ & Sum of Ranks \\
\hline Result & Warp & $\begin{array}{c}21 \\
22.10\end{array}$ & 464.00 \\
\hline & Weft & $\begin{array}{c}21 \\
20.90\end{array}$ & 439.00 \\
\hline & Total & 42 & \\
\hline
\end{tabular}

Table 9. Test statistics

\begin{tabular}{|l|c|}
\hline & Result \\
\hline Mann-Whitney U & 208.000 \\
\hline Wilcon W Z & 439.000 \\
\hline &,- 315 \\
\hline Asymp.Sig (2-tailed) &, 753 \\
\hline
\end{tabular}

a. Grouping Variable: warp weft

Table 10. Ranks

\begin{tabular}{|c|c|c|c|}
\hline & $\begin{array}{c}\text { Breaking } \\
\text { Elongation } \\
\text { Tearing }\end{array}$ & $\mathrm{N}$ & Mean Rank \\
\hline Result & Breaking & 14 & 35.50 \\
\hline & Elongation & 14 & 21.50 \\
\hline & Tearing & 14 & 7.50 \\
\hline & Total & 42 & \\
\hline
\end{tabular}

Table 11. Test Statistics

\begin{tabular}{|c|c|}
\hline & Result \\
\hline Qi-Square & 36.527 \\
\hline df & 2 \\
\hline Asymp. Sig. &, 0001 \\
\hline
\end{tabular}

a. Kruskal wallis test, b. Grouping variable breaking elongation tearing
Table 12. Ranks

\begin{tabular}{|c|c|c|c|}
\hline & Recipe & N & Mean Rank \\
\hline Result & Raw fabric & 6 & 20.50 \\
\hline & PA 3a & 6 & 23.83 \\
\hline & PA 1a & 6 & 22.17 \\
\hline & PA 2a & 6 & 21.58 \\
\hline & PA 3b & 6 & 22.25 \\
\hline & PA 2b & 6 & 21.08 \\
\hline & PA 1b & 6 & 19.08 \\
\hline & Total & 42 & \\
\hline
\end{tabular}

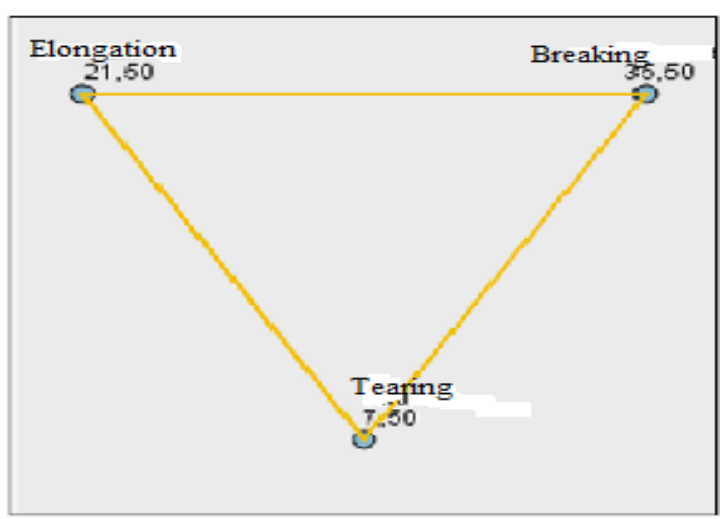

Figure 8. Pairwise comparisons of breaking elongation tearing

Table 13. Each node shows the sample average rank of breaking elongation tearing

\begin{tabular}{|l|c|c|c|c|c|}
\hline $\begin{array}{l}\text { Sample 1- } \\
\text { Sample 2 }\end{array}$ & $\begin{array}{c}\text { Test } \\
\text { Statistic }\end{array}$ & $\begin{array}{c}\text { Std. } \\
\text { Error }\end{array}$ & $\begin{array}{c}\text { Std. } \\
\text { Test } \\
\text { Statistic }\end{array}$ & Sig. & $\begin{array}{c}\text { Adj. } \\
\text { Sig. }\end{array}$ \\
\hline $\begin{array}{l}\text { Tearing- } \\
\text { Elongation }\end{array}$ & 14.000 & 4.633 & 3.022 &, 003 &, 008 \\
\hline $\begin{array}{l}\text { Tearing- } \\
\text { Breaking }\end{array}$ & 28.000 & 4.633 & 6.044 &, 000 &, 000 \\
\hline $\begin{array}{l}\text { Elongation- } \\
\text { Breaking }\end{array}$ & 14.000 & 4.633 & 3.022 &, 003 &, 008 \\
\hline
\end{tabular}

Each row tests the null hypothesis that the Sample 1 and Sample 2 distributions are the same.

Asymptotic significances (2-sided tests) are displayed. The significance level is 0.05 .

\section{CONCLUSIONS}

1. $100 \%$ cotton fabric was used for this study in denim shirt fabric, acrylic coating process has 
been applied with copper, zinc oxide particles. After coating, the breaking strength (newton), elongation at break (\%) and tear strength (newton) were determined experimentally and the results were evaluated. In this study, cotton fabric was functionalized by cross-linking of polycarboxylic acid (BTCA and CA). In addition, BTCA and CA treatment could improve significantly the breaking strength and tearing strength of cotton fabrics. Coated woven fabrics by polyacrylate binder become mild. Breaking strengths in the warp and weft directions generally increased after the coating process. Coated fabrics with polyacrylate binder have a stronger structure compared to uncoated ones which is due to the higher density in the warp direction. Therefore, higher breaking strength results were obtained. In the fabric with less weft density, less number of yarns will resist the load and the breaking strength of the fabric in weft direction decreases. It was concluded that 5\% concentration of BTCA was enough to obtain durable breaking strength.

2. When the elongation of this treated fabric were compared, it was determined that $\mathrm{ZnO}<5 \mu \mathrm{m}+\mathrm{BTCA}$ had the best $(28 \%)$ elongation.

3. The mechanical properties of the polyacrylate binder coating can have a major effect on the tear properties of coated woven fabrics. The tear properties of a polyacrylate binder coated woven fabric depend on the structure of crosslinking used. Since there is a loose structure in twill fabrics, the yarns slide over each other and it tears later. In this study, since medium hard polyacrylate binder, cross-linker and microparticles are applied to the fabric, it increases the friction between the yarns. It causes a decrease in tear strength.

4. Application to the better soft polyacrylate polymer with polycarboxyclic crosslinking increased the breaking load of the coated fabric. Greater polyacrylate polymer led to a greater tensile load.
5. Utilization of the greater polycarboxylic crosslinking to a woven fabrics increased its flexible. In other words, coatings that add a noticeable mass to woven fabrics soften them. An elastic structure is generated owing to the cross-linking between BTCA, CA and cellulose. This leads to decrease in elongation at break.

6. Polycarboxylic acid crosslinkers generate an ester type crosslink with cotton. 1,2,3,4butantetracarboxylic acid (BTCA) was more effective crosslinker compared to citric acid monohydrate (CA) owing to the four carboxylic groups in its structure. The better crosslinking of the fabrics treated with BTCA was caused by the existence of the four carboxylic acid groups in BTCA, which could generate the hydroxyl ion.

7. On the basis of the findings of this study, another study has been designed in which the combined effect of different cross-linkers, breaking strength, tearing strength will be studied.

8. According to the results of the one-way analysis of variance, it was found that the prescriptions were statistically significant at the $95 \%$ confidence level on the rupture, elongation and tear test results.

\section{ACKNOWLEDGMENT}

Editors and Publishing Coordinators of ÇÜMF thank to all authors and reviewers for their contributions.

\section{REFERENCES}

1. Soljačić, I., 1993. Textile Coating. Tekstil, 42(12), 673-686.

2. Mogahzy, Y.E., 2009. Engineering Textiles. Integrating the Design and Manufacture of Textile Products. The Textile Institute, Woodhead Publishing Limited, Cambridge, England.

3. Fung, W., Hardcastle, M., 2001. Textiles 
Automotive Engineering. The Textile Institute, Woodhead Publishing Limited, Cambridge, England.

4. Brandrup, J., Immergut, E.H., Grulke, E.A., 1999. Polymer Handbook. $4^{\text {th }}$ ed. New York: John Wiley \& Sons.

5. Fenichell, S., 1996. Plastic: The Making of a Synthetic Century. New York: Harper Collins.

6. Seymour, R.B., Giant, C.E., 1990. Molecules. New York: John Wiley and Sons, Inc.

7. Ulrich, H., 1982. Introduction to Industrial Polymers. Munich: Hanser.

8. Skoko, M., 1998. Investigations of Properties and Multiaxial Strength and Degenerations of Coated Textile Fabrics. Tekstil, 47(7), 339-344.

9. Kong, I., Yang, C.Q., Wei, W., Lickfield, G.C., 1998. Mechanical Strength of Durable Press Finished Cotton Fabrics: Part I: Effects of Acid Degradation and Crosslinking of Cellulose by Polycarboxylic Acids. Textile Research.Journal., Nov. 1, 68, 865-870.

10. Yang, C.Q., Qian, L., Lickfield, G.C., 2001. Mechanical Strength of Durable Press Finished Cotton Fabric. Part IV: Abrasion Resistance. Textile Research Journal, June 1(71), 543-548.

11. Harper, R.J., Little, H.W., Blanchard, E.J., 1972. Cotton Yarn and Fabric Treatments Using Polymers with Various Glass-transition Temperatures. Textile Research Journal, Oct 1(42), 569-575.

12. Yamamato, K., 1982 . Crease-resistance Finishing of Cotton Fabrics with Acrylate Copolymers and Dihydroxy Dimethylethylene Urea. Textile Research Journal, Jun 1(52), 363-369.

13. Harper, R.J., Blanchard, E.J., Donoghue, M.J., 1970. Effect of Polyvinyl Alcohol on Textile Finishes. American Dyestuff Reporter, 59(12), 15.

14. Abo-Shosha, M.H., Ibrahim, N.A., 1992. Water Soluble Polyether Polyurethanes as Finishing Additives in Easy Care Finishing of Cotton Fabrics. Science International Lahour, 4(2), 163.

15. Hebeish, A., Amin, S.A., Nassar, F., Ibrahim, N.A., Hanna, H.L., 1982. Cellulose Chemistry and Technology, 16, 405.

16. Yang, C.Q., 2013. Crosslinking: a Rout to Improve Cotton Performance. AATCC
Review,13,43-52.

17. Yang, C.Q., Wei, W., 2000. Mechanical Strength of Durable Press Finished Cotton Fabric. Textile Research Journal, 70(2), 143-147.

18. Refaie, R., 2005. Polymeric Additives for Improving Performance Properties of Cotton Fabric Crosslinked with 1,2,3,4Butanetetracarboxylic Acid. $8^{\text {th }}$ Arab International Conference on Polymer Science \& Technology, 27-30 Nov, Egypt.

19. Chen,W., Gary, C., Lickfield \& Others, 2001. Abrasion Resistance of Durable Press Finish Cotton,.National Textile Center Annual Report: November, C00-C01: 1-8.

20. Xu, W., Li, Y., 2000. Cotton Fabric Strength Loss from Treatment with Polycarboxylic Acids for Durable Press Performance. Textile Research Journal, 70(11), 957-961.

21. Sauperl, O., Stana-Kleinschek, K., 2009. Cotton Cellulose 1,2,3,4 (BTCA) Buthanetetracarboxylic Acid Crosslinking Monitored by Some Physical-chemical Methods. Textile Research Journal, 79(9), 780-791.

22. Sauperl, O., Stana-Kleinschek, K., 2009. Differences Between Cotton and Viscose Fibers Crosslinked with BTCA. Textile Research. Journal, 80(4), 383-392.

23. Xu, W., 2003. Effect of Cross-linking Treatment on the Crystallinity, Crystallite Size, and Strength of Cotton Fibers. Textile Research Journal, 73(5), 433-436.

24. Spencer, T.P., Hauser, P.B., Smith, B., 2006. Optimization of Ionic Cross-linking. North Carolina State University, 98.

25. Hashem, M., Elshakankery, M.H., El-Aziz, S.M.A., Fouda, M.G., Fahmy, H.M., 2011. Improving Easy Care Properties of Cotton Fabric via Dual Effect of Ester and Ionic Crosslinking. Carbohydrate Polymers, 86, 1692-1698.

26. Taylor, M., 1999. Technology of Textile Properties. Forbes Publications Ltd, London, 204.

27. Yao, W., Wang, B., Ye, T., Yang, Y., 2013. Durable Press Finishing of Cotton Fabrics with Citric Acid: Improvement of Whiteness and Wrinkle Cure by Polyol Extenders. Industrial 
Engineering Chemistry Research, 52, $16118-16127$.

28. Schramm, C., Rinderer, B., 1999. Influence of Additives on the Generation of Unsaturated PCAs Generated During Durable-press Curing with Citric Acid. Color Technology ,115, 306311.

29. Morris, C.E., Morris, N.M., Trask-Morrell, B. J., 1996. Interaction of meso-1,2,3,4Butanetetra Carboxylic Acid with PhosphorusIncluding Catalysts for Esterification Crosslinking of Cellulose. Industrial \& Engineering Chemistry Research, 35, 950-953.

30. Yang, C.Q., Wang, X., 1996. Generation of Cyclic Anhydride Intermediates and Esterification of Cotton Cellulose by Multifunctional Carboxylic Acids: An Infrared Spectroscopy Study. Textile Research Journal, 66, 595-603.

31. Ibrahim, N.A., Abo-Shosha, M.H., Gaffar, M.A., 2001. Eco-friendly Durable Press Finishing of Cellulose-including Fabrics. Journal of Applied Polymer Science, 84, 2243-2253.

32. Welch, C.M., 1988. Tetra Carboxylic Acids as Generalaldehyde-free Durable Press Finishing Agents Part I: Catalyst, Additive, and Durability Studies 1. Textile Research Journal, 58, 480-486.

33. Choi, H.M., Welch, C.M., Morris, N.M., 1994. Nonphosphorus Catalysts for Generatealdehyde-free DP Finishing of Cotton with 1,2,3,4-Butanetetracarboxylic Acid: Part II: Sodium Salts of Fumaric, Maleic, and Itaconic Acids. Textile Research Journal, 64, 501-507.

34. Hashem, M., Elshakankery, M.H., El-Aziz, S.M.A., Fouda, M.M.G., Fahmy, H.M., 2011. Improving Easy Care Properties of Cotton Fabric via Dual Effect of Ester and Ionic Crosslinking. Carbohydrate Polymers, 86, 1692-1698.

35. Sungur, E.G., 2020. Dokuma Kumaşların Yapısal ve Mekanik Özellikleri ile Dökümlülüğü Arasındaki İlişkinin İncelenmesi. Yüksek Lisans Tezi, Uludağ Üniversitesi, Fen Bilimleri Enstitüsü, Bursa, 115. 